\section{The Biological Meaning of Race}

\author{
S. Joshua Swamidass (D)
}

https://doi.org/10.54739/mhou

$\mathbf{W}$ hat is the meaning of race? How are we the same and how are we different? At Peaceful Science, we gather around the grand question of what it means to be human. We gather around the questions of ancestry. Continuing a centuries long conversation, alongside many others, we wonder about the meaning of race.

Earlier this year, I told Christianity Today about one of my most vivid lessons in researching a book about origins,

One thing I've learned is it's really common for people to bring race into questions about human origins, often to attack those with whom they disagree. We all inherit that legacy of racism. Origins is often approached from a very whitewashed perspective. It doesn't really engage the concerns of people of color, who are often underrepresented in the conversations. What I found, as a dark Indian, is that these questions of origins are actually very closely tied to our concerns about our worth and dignity in the world.

This week, I was interviewed on National Public Radio (NPR) about the science and theology of race. The great population geneticist Alan Templeton also commented, and the recording is worth listening.

NPR interviewed Kennedy Mitchum right before us. She is a young woman in St Louis who just convinced Merriam-Webster to revise their definition of "racism." Her story is important. She explained her experience with racism. She was ignored and dismissed by selective quotes from the dictionary definition of racism. Minorities, we find, are often silenced by dictionaries.

“Word games," some might say. Don't sniff. Definitions matter...much more than we think they do. Our perceptions can shift dramatically based on how authoritative sources define contested terms. Changing the dictionary definition of "racism" is a milestone event, giving voice, in a place of authority, to one who was silenced before.

Discussing race and racism is complex and difficult. In $\underline{T h e}$ Genealogical Adam and Eve, I explained some of the history of racism in both science and theology to reckon. If you go back about 150 years ago in science, and 500 years ago in theology, people have been wondering about this idea of polygenesis, a long-dominant theory of disparate human origins. Many scientists believed that there was a hierarchy of biologically distinct races, with Europeans at the

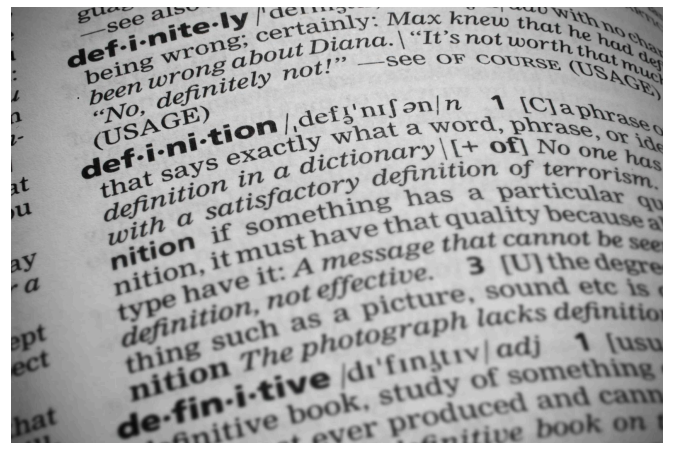

top. That understanding of race strongly influenced how our ancestors set up society.

Though there is a dark history of scientific racism, we can now approach the science of race with confidence. Genetic science since the 1960s and '70s strongly disproved such ideas. The caller into the NPR interview was an important reminder to me. He was so certain that race was an essential biological category, but he missed what we learned from genetics.

So, in what ways is race real? In what ways is it an illusion? We were fortunate, also, to interview both Quayshawn Spencer and Adam Rutherford about their work. Jordan Mantha recently hosted a book club on Steve Olson's book. We have been fielding questions about this from several people in the last month. I have been recommending some good books to read about the meaning of race.

1. Mapping Human History: Genes, Race, and Our Common Origins by Steve Olson.

2. Rethinking Race: The Case for Deflationary Realism by Michael O. Hardimon.

3. What Is Race?: Four Philosophical Views by Joshua Glasgow, Sally Haslanger, Chike Jeffers, and Quayshawn Spencer.

4. How To Argue With A Racist: History, Science, Race and Reality by Adam Rutherford.

5. Who We Are and How We Got Here: Ancient DNA and the New Science of the Human Past by David Reich.

There is debate about how precisely to understand race. Still, everyone agrees that the biologically-thick, essentialist understanding of race, once common, is false. Polygenesis looms over history, shaping how society was set up. But polygenesis was false. We are far more alike than we first perceived, linked together into a common family.

It turns out that the biological reality of race is deflationary, in the best sense of the word. We've understood our differences to be rooted in our essential nature, but maybe they are not. So, maybe some of the ways the world is can be changed. 


\section{References}

https://www.christianitytoday.com/ct/2020/january-web-only/ genealogical-adam-eve-evolution-joshua-swamidass.html http://potiphar.jongarvey.co.uk/2017/10/06/the-racist-adam https://news.stlpublicradio.org/post/how-2-st-louisans-are-refiningcontemporary-understandings-race-racism\#stream/0

https://peacefulscience.org/books/genealogical-adam-eve/ https://www.merriam-webster.com/dictionary/polygenesis https://peacefulscience.org/articles/quayshawn-spencer-race/ https://peacefulscience.org/articles/rutherford-racist/ https://discourse.peacefulscience.org/t/_/10225 https://peacefulscience.org/books/mapping-human-history/ https://peacefulscience.org/books/rethinking-race/ https://peacefulscience.org/books/what-is-race/ https://peacefulscience.org/books/argue-with-racist/ https://peacefulscience.org/books/who-we-are-how-we-got-here/ 